\title{
Magnolia polyphenols attenuate oxidative and inflammatory responses in neurons and microglial cells
}

Dennis Y Chuang ${ }^{1,2,3 \dagger}$, Ming-Huan Chan ${ }^{4,5 \dagger}$, Yijia Zong ${ }^{1,2,3+}$, Wenwen Sheng ${ }^{5}$, Yan He ${ }^{5,6}$, Jing Hua Jiang ${ }^{3,5}$, Agnes Simonyi ${ }^{1,2,3,5}$, Zezong Gu $u^{1,2,3,7}$, Kevin L Fritsche ${ }^{3,8}$, Jiankun Cui ${ }^{1,2,3,7}$, James C Lee ${ }^{1,9}$, William R Folk ${ }^{3,5}$, Dennis B Lubahn ${ }^{3,5,8}$, Albert Y Sun ${ }^{1,2,3,7}$ and Grace $Y$ Sun ${ }^{1,2,3,5,7^{*}}$

\begin{abstract}
Background: The bark of magnolia has been used in Oriental medicine to treat a variety of remedies, including some neurological disorders. Magnolol (Mag) and honokiol (Hon) are isomers of polyphenolic compounds from the bark of Magnolia officinalis, and have been identified as major active components exhibiting anti-oxidative, antiinflammatory, and neuroprotective effects. In this study, we investigate the ability of these isomers to suppress oxidative stress in neurons stimulated by the ionotropic glutamate receptor agonist $\mathrm{N}$-methyl-D-aspartate (NMDA) and oxidative and inflammatory responses in microglial cells activated by interferon- $\gamma$ (IFN $\gamma$ ) and lipopolysaccharide (LPS). We also attempt to elucidate the mechanism and signaling pathways involved in cytokine-induced production of reactive oxygen species (ROS) in microglial cells.
\end{abstract}

Methods: Dihydroethidium (DHE) was used to assay superoxide production in neurons, while CM-H2DCF-DA was used to test for ROS production in murine (BV-2) and rat (HAPI) immortalized microglial cells. NADPH oxidase inhibitors (for example, diphenyleneiodonium (DPI), AEBSF, and apocynin) and immunocytochemistry targeting p47phox and gp91phox were used to assess the involvement of NADPH oxidase. Western blotting was used to assess iNOS and ERK1/2 expression, and the Griess reaction protocol was employed to determine nitric oxide (NO) concentration.

Results: Exposure of Hon and Mag (1-10 $\mu \mathrm{M})$ to neurons for $24 \mathrm{~h}$ did not alter neuronal viability, but both compounds $(10 \mu \mathrm{M})$ inhibited NMDA-stimulated superoxide production, a pathway known to involve NADPH oxidase. In microglial cells, Hon and Mag inhibited IFN $ү \pm$ LPS-induced iNOS expression, NO, and ROS production. Studies with inhibitors and immunocytochemical assay further demonstrated the important role of IFNy activating the NADPH oxidase through the p-ERK-dependent pathway. Hon and, to a lesser extent, Mag inhibited IFNy-induced p-ERK1/2 and its downstream pathway for ROS and NO production.

Conclusion: This study highlights the important role of NADPH oxidase in mediating oxidative stress in neurons and microglial cells and has unveiled the role of IFNY in stimulating the MAPK/ERK1/2 signaling pathway for activation of NADPH oxidase in microglial cells. Hon and Mag offer anti-oxidative or anti-inflammatory effects, at least in part, through suppressing IFNy-induced p-ERK1/2 and its downstream pathway.

Keywords: ERK1/2, Honokiol, IFNy, iNOS/NO, Inflammatory, Magnolol, Microglial cells, Oxidative, NADPH oxidase, Neurons

\footnotetext{
* Correspondence: SunG@missouri.edu

${ }^{\dagger}$ Equal contributors

'Interdisciplinary Neuroscience Program, University of Missouri, Columbia, MO, USA

${ }^{2}$ Center of Translational Neuroscience, School of Medicine, University of

Missouri, Columbia, MO, USA

Full list of author information is available at the end of the article
}

\section{Biomed Central}

(c) 2013 Chuang et al.; licensee BioMed Central Ltd. This is an Open Access article distributed under the terms of the Creative Commons Attribution License (http://creativecommons.org/licenses/by/2.0), which permits unrestricted use, distribution, and reproduction in any medium, provided the original work is properly cited. 


\section{Background}

The bark of the magnolia tree has been used in a number of traditional herbal medicinal preparations in Oriental countries for thousands of years [1]. Magnolia officinalis (China) and Magnolia obovata (Japan) contain a rich source of biologically active compounds, including alkaloids, coumarins, flavonoids, lignans, neolignans, and terpenoids [2,3]. According to in vitro and in vivo studies, and recent clinical trials, there is strong evidence that these constituents play an important role in the treatment of a plethora of ailments by reducing allergic and asthmatic reactions, and suppressing anxietic and angiogenic responses [4-9].

Magnolol (Mag) and honokiol (Hon) (Figure 1) are polyphenolic compounds from Magnolia officinalis belonging to the neolignan family. Recent evidence that these compounds exert beneficial effects in neurological disorders, such as anxiety, depression, stroke, Alzheimer's disease, and Parkinson's disease, has attracted great attention and further investigation of their molecular mechanism and specific targets [10-15]. Neuronal excitation due to stimulation by the ionotropic glutamate receptor agonists is known to elicit a rapid influx of calcium, which triggers downstream pathways leading to the production of reactive oxygen species (ROS) and mitochondrial dysfunction $[16,17]$. Understanding the underlying mechanism by which Magnolia compounds suppress neuronal excitotoxicity may help explain their ameliorating actions in disease models.

Studies with cell models have demonstrated antiinflammatory effects of Hon and Mag in mitigating cytokine-induced nitric oxide (NO) production, expression of inducible nitric oxide synthase (iNOS), and generation of prostaglandins and leukotrienes [18-20]. This type of inflammatory response is important in microglial cells because their activation has been the basis of a number of neurodegenerative diseases. Although cytokines and LPS have been shown to activate microglial cells and induce ROS and NO production, mechanistic details within the signaling pathways leading to this type of oxidative and inflammatory responses have not been clearly elucidated.
In this study, we aim to test the ability for Hon and Mag to suppress oxidative and inflammatory responses in neurons and microglial cells. Studies with neurons were based on the excitotoxic model demonstrating the involvement of NADPH oxidase in NMDA-stimulated ROS production [16]. Studies with microglial cells demonstrated that NADPH oxidase was also involved in mediating cytokine and LPS-induced ROS production. In addition, our studies further unveiled the important role of the IFN $\gamma$-ERK1/2 signaling pathway for ROS production and the ability of Hon and Mag to suppress this pathway in microglial cells.

\section{Materials and methods Materials}

Honokiol (lot number M8P0236) and magnolol (lot number M8F3374) ( $\geq 98 \%$ pure based on HPLC) were purchased from Nacalai Tesque, Inc. (Kyoto, Japan). These compounds were dissolved in dimethyl sulfoxide (DMSO) as stock solutions. DMEM, penicillin, streptomycin, 0.05\% (w/v) trypsin/EDTA, and PBS were obtained from GIBCO (Gaithersburg, MD). Interferon- $\gamma$ (IFN $\gamma$ ) was purchased from R\&D Systems (Minneapolis, MN). Lipopolysaccharide (LPS) (rough strains) from Escherichia coli F583 (Rd mutant) and methylthiazolyldiphenyl-tetrazolium bromide (MTT) were obtained from Sigma-Aldrich (St. Louis, MO). The AlamarBlue ${ }^{\mathrm{TM}}$ kit was from Invitrogen (Carlsbad, CA). Fetal bovine serum was from Atlanta Biologicals (Lawrenceville, GA). Antibodies used for Western blotting include: goat anti-rabbit IgG-horseradish peroxidase, goat anti-mouse IgG-horseradish peroxidase, and iNOS polyclonal (Santa Cruz Biotechnology, Santa Cruz, CA); monoclonal anti- $\beta$-actin peroxidase (Sigma-Aldrich, St. Louis, MO); ERK1/2, phospho-ERK1/2, (Cell Signaling, Beverly, MA). Antibodies used for immunocytochemical staining include rabbit anti-p47phox antibodies (Calbiochem, Billerica, MA), mouse anti-gp91phox (Thermo Fisher, Waltham, MA), goat-anti-rabbit Alexa fluor 488 (Jackson Immunoresearch, West Grove, PA), and goat-anti-mouse Alexa fluor 549 (Jackson Immunoresearch, West Grove, PA).

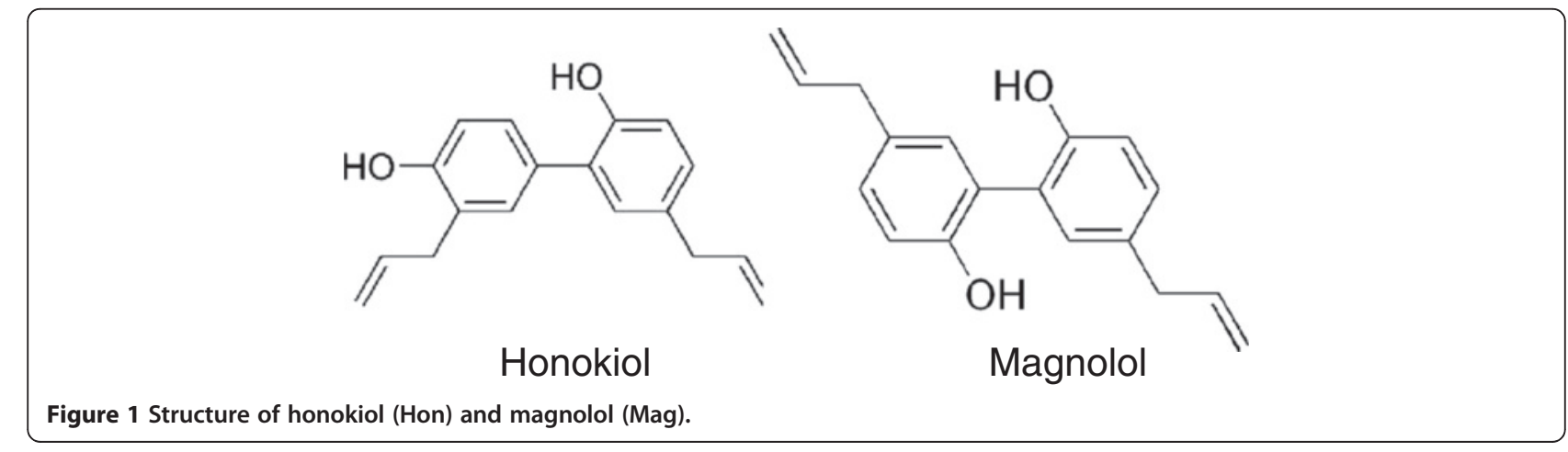


For ROS detection, CM-H2DCFDA (DCF) was obtained from Invitrogen, Inc. (Carlsbad, CA), and dihydroethidium (DHE) from Sigma-Aldrich (St. Louis, MO). Inhibitors used in this study include: MEK inhibitor U0126 (Cell Signaling, Beverly, MA), 4-(2-aminoethyl)-benzenesulfonylfluoride (AEBSF, Calbiochem, San Diego, CA), diphenyleneiodonium (DPI) and apocynin (Sigma-Aldrich, St. Louis, MO).

\section{Cell culture}

Preparations of primary cortical neuron cells involved pregnant E17 Sprague-Dawley rats (Harlan, IN, USA). All animal care and experimental protocols were carried out in accordance with National Institutes of Health (NIH) guidelines and with permission from the University of Missouri Animal Care and Use Committee (protocol \#6728). Primary cortical neurons were prepared from the cerebral cortices of E17 Sprague-Dawley rat embryos as described [21]. Briefly, cerebral cortices were dissected and meninges removed. The tissues were suspended in 3 $\mathrm{ml} 0.05 \%(\mathrm{w} / \mathrm{v})$ trypsin/EDTA and incubated for $30 \mathrm{~min}$ at $37^{\circ} \mathrm{C}$. The cell suspension was triturated through a fineburned-tip glass pipette until tissues were homogenized. The filtrate was centrifuged at $1000 \mathrm{~g}$ for $1 \mathrm{~min}$ and resuspended in 10\% FBS in DMEM containing 100 units $/ \mathrm{ml}$ penicillin and streptomycin $(100 \mu \mathrm{g} / \mathrm{ml})$. Finally, cells were plated in 24-well plates for MTT analysis and $35 \mathrm{~mm}$ dishes for ROS detection. The plates were precoated with poly-L-lysine (Sigma-Aldrich, St. Louis, MO) the day before plating and incubated overnight. Four hours after plating, culture medium was completely changed to B27 supplemented Neurobasal medium containing 100 units $/ \mathrm{ml}$ penicillin, $100 \mu \mathrm{g} / \mathrm{ml}$ streptomycin, and glutamine. Culture was maintained by changing $1 / 2$ volume of B27 medium in each well every 4 days. Experiments were conducted 8 days after plating, to ensure adequate culture maturation.

The immortalized mouse BV-2 and rat HAPI microglial cells were cultured as described previously [22]. Briefly, cells were cultured in $75 \mathrm{~cm}^{2}$ flasks with DMEM (high glucose) supplemented with 10\% FBS containing 100 units $/ \mathrm{ml}$ penicillin and $100 \mu \mathrm{g} / \mathrm{ml}$ streptomycin, and maintained in a $5 \% \mathrm{CO}_{2}$ incubator at $37^{\circ} \mathrm{C}$. For subculture, cells were removed from the culture flask with a scraper, resuspended in the culture medium and subcultured in 12, 24, or 96-well plates for experiments.

\section{Assessing cell viability}

Two assay protocols were used to assess neuron viability after exposure to Hon and Mag. Since mitochondrial dysfunction is an initial step in apoptotic pathways that lead to neuronal cell death, the MTT assay was used to determine mitochondrial dysfunction. In this assay, neurons were cultured in 24-well plates and treated with Hon or Mag (1 to $10 \mu \mathrm{M}$ ) at $37^{\circ} \mathrm{C}$ for $24 \mathrm{~h}$. After treatment, culture medium was removed and $1 \mathrm{ml}$ of MTT reagent $(0.5 \mathrm{mg} / \mathrm{ml})$ dissolved in serum-free DMEM was added to each well. The plates were incubated for $3 \mathrm{~h}$ at $37^{\circ} \mathrm{C}$, and the formazan particles in each well were dissolved in $500 \mu \mathrm{l}$ of DMSO. After shaking the plates at room temperature for $5 \mathrm{~min}$, absorbance was read at $540 \mathrm{~nm}$ using a Synergy4 Plate Reader (BioTek Instruments, Inc., Fisher Scientific, St. Louis, MO, USA.).

AlamarBlue $^{\mathrm{TM}}$ is a cell-permeable nonfluorescent dye, which can be converted into red fluorescence on reductive reactions within live cells. This assay was used to determine the extent of neuronal viability after exposure to Hon and Mag ( 1 to $10 \mu \mathrm{M}$ ). In this assay, neurons were cultured in 24-well plates and then treated with Hon or Mag $(1$ to $10 \mu \mathrm{M})$ at $37^{\circ} \mathrm{C}$ for $24 \mathrm{~h}$. After treatments, $100 \mu \mathrm{l}$ of AlamarBlue ${ }^{\mathrm{TM}}$ was added to each well and neurons were further incubated at $37^{\circ} \mathrm{C}$ for $3 \mathrm{~h}$. Absorbance was read at $570 \mathrm{~nm}$ using the Synergy4 Plate Reader (BioTek) with measurement at $600 \mathrm{~nm}$ as a reference.

\section{Measurement of superoxide in neurons and ROS production in microglial cells}

Dihydroethidium (DHE) is oxidized by superoxide anions to produce fluorescent ethidium, which is intercalated into DNA, and can be quantified by summing the fluorescence within the cell [23]. This protocol has been successfully used to measure superoxide production in neurons $[16,21]$. Neurons were cultured on 35 $\mathrm{mm}$ dishes precoated with poly-L-lysine. Neurons were then treated with Hon or Mag $(10 \mu \mathrm{M})$ for $30 \mathrm{~min}$, and exposed to NMDA $(100 \mu \mathrm{M})$ for $30 \mathrm{~min}$ in phenol red free Neurobasal medium with $0.5 \mathrm{mg} / \mathrm{ml}$ BSA. At 30 min prior to image acquisition, cells were loaded with DHE $(10 \mu \mathrm{M})$ and incubated at $37^{\circ} \mathrm{C}$. Fluorescence images were acquired using a Nikon TE-2000 U inverted microscope with a $20 \times$ NA 0.95 objective and a cooled charge-coupled device (CCD) camera controlled with a computer running MetaView imaging software (Universal Imaging, West Chester, PA). The fluorescence excitation source was controlled with a Uni-Blitz mechanical shutter. For image acquisition, a short exposure time (200 ms) and low-intensity excitation light were applied to minimize photobleaching. Digital images were analyzed using the MetaView software with automatic background subtraction. Threshold fluorescence levels were obtained for each image prior to the quantification. For each field, the total fluorescence was measured and expressed as the average fluorescence normalized by the total number of cells. For each treatment group, at least three random images from the same dish were captured and analyzed, and each treatment was repeated three times independently for statistical analysis. 
For measurement of ROS production in microglial cells, we adopted a protocol using CM-H2DCF-DA, a compound that becomes fluorescent upon interacting with $\mathrm{ROS}$ including $\mathrm{H}_{2} \mathrm{O}_{2}$ [24]. In this study, microglial cells were seeded in 96-well plates, and when they became $90 \%$ confluent, they were serum-starved for $4 \mathrm{~h}$. Cells were treated with cytokines or LPS, or both, for different times and CM-H2DCF-DA $(10 \mu \mathrm{M})$ was added $1 \mathrm{~h}$ before measurement. In some experiments, cells were pretreated with U0126 or Hon or Mag for $1 \mathrm{~h}$ prior to stimulating with IFN $\gamma$ for $11 \mathrm{~h}$, the CM-H2DCF-DA $(10 \mu \mathrm{M})$ was then added and the cells were further incubated for $1 \mathrm{~h}$. The fluorescent intensity of DCF was measured using the Synergy4 microplate reader with an excitation wavelength of $490 \mathrm{~nm}$ and an emission wavelength of $520 \mathrm{~nm}$.

\section{Measurement of NO}

Cells were serum-starved in phenol red free DMEM for $3 \mathrm{~h}$, followed by pretreatment of compounds of interest for $1 \mathrm{~h}$. Cells were then treated with IFNy and LPS or IFNy alone and incubated at $37^{\circ} \mathrm{C}$ for $16 \mathrm{~h}$. Nitric oxide released from cells was converted to nitrite in the culture medium, which was determined using the Griess reagent protocol. Aliquots $(50 \mu \mathrm{l})$ of culture medium were transferred to a 96-well plate and incubated with $50 \mu \mathrm{l}$ of Reagent A ( $1 \%$ sulfanilamide in $5 \%$ phosphoric acid) per well for $10 \mathrm{~min}$ at room temperature, covered and in the dark. This was followed by incubation with $50 \mu \mathrm{l}$ of reagent $\mathrm{B}(0.1 \%, \mathrm{w} / \mathrm{v}, \mathrm{N}-1$-napthylethylenediamine dihydrochloride, Sigma-Aldrich) per well for $10 \mathrm{~min}$ at room temperature, covered and in the dark. Serial dilutions of sodium nitrite ( 0 to $100 \mu \mathrm{M}$ ) were used to generate the nitrite standard reference curve. Following the incubation period, absorbance at $543 \mathrm{~nm}$ was measured using the Synergy4 microplate reader.

\section{Western blot analysis}

Cells were harvested in lysis radioimmunoprecipitation assay (RIPA) buffer containing $50 \mathrm{mM}$ Tris- $\mathrm{HCl}(\mathrm{pH}$ 7.5), $150 \mathrm{mM} \mathrm{NaCl}, 1 \%$ Nonidet P-40, 0.5\% sodium deoxycholate, and $0.1 \%$ sodium dodecyl sulfate (SDS). The extract was centrifuged at $10,000 \mathrm{~g}$ for $15 \mathrm{~min}$ at $4^{\circ} \mathrm{C}$ to remove cell debris. Protein concentration was determined with the BCA protein assay kit (Pierce Biotechnology, Rockford, IL). For each sample, $5 \mu \mathrm{g}$ of protein was loaded and resolved in 8\% SDS-PAGE and run at $100 \mathrm{~V}$. After electrophoresis, proteins were transferred to $0.45 \mu \mathrm{m}$ nitrocellulose membranes at $300 \mathrm{~mA}$ for $3 \mathrm{~h}$. Membranes were blocked in Tris-buffered saline (TBS), $\mathrm{pH} 7.4$, with $0.1 \%$ Tween 20 (TBS-T) containing 5\% nonfat milk for $1 \mathrm{~h}$ at room temperature. For different experiments, the blots were incubated with ERK1/2 (1:2000), phospho-ERK1/2 (1:2000), iNOS polyclonal
(1:1000) antibodies overnight at $4^{\circ} \mathrm{C}$. After repeated washing with TBS-T, blots were incubated with goat anti-rabbit IgG- horseradish peroxidase (1:4000) or goat anti-mouse IgG- horseradish peroxidase (1:2000) for $1 \mathrm{~h}$ at room temperature. The blots were then washed three times with TBS-T. Immunolabeling was detected by chemiluminescence ECL/WestPico/femto. For loading control, blots were incubated with monoclonal anti- $\beta$-actin peroxidase $(1: 30,000)$. For quantification, blots were scanned and the intensity of protein bands was measured as optical density using the QuantityOne program (BioRad, Hercules, CA).

\section{Immunostaining of p47phox and gp91phox in microglial cells}

BV-2 microglia cells were serum-starved for $4 \mathrm{~h}$, followed by stimulation with IFNY $(10 \mathrm{ng} / \mathrm{ml})$ for $12 \mathrm{~h}$. The cells were fixed in $4 \%$ paraformaldehyde for $15 \mathrm{~min}$ and then permeabilized with $0.1 \%$ Triton X-100 in PBS for $30 \mathrm{~min}$. Cells were incubated with $10 \%$ normal goat serum in $0.005 \%$ Triton X-100 in PBS for $60 \mathrm{~min}$. Cells were then incubated overnight in $0.5 \%$ normal goat serum in $0.005 \%$ Triton X-100 in PBS containing primary antibodies: rabbit anti-p47phox antibodies (1:500; Calbiochem) and mouse anti-gp91phox antibodies (1:500; Thermo Fisher). The next day, cells were incubated in $0.005 \%$ Triton X-100 in PBS containing secondary antibodies, goat-anti-rabbit Alexa fluor 488 (Jackson Immunoresearch) and goat-antimouse Alexa fluor 549 (Jackson Immunoresearch) for 60 min, followed by nuclear counterstaining in PBS containing $1 \mu \mathrm{g} / \mathrm{ml}$ of 4,6-diamidine-2-phenylindole dihydrochloride (Pierce) for $10 \mathrm{~min}$. The coverslips were then mounted on fluoromount (Sigma-Aldrich) and sealed with nail polish. Fluorescence photomicrographs were captured using a Leica DMI 6000B fully automated epifluorescence microscope (Leica Microsystems Inc., Buffalo Grove, IL) as serial $z$-stack images and processed for deconvolution with AF6000 applications.

\section{Statistical analysis}

Data are presented as mean \pm standard error of the mean (SEM). Results were analyzed by one-way analysis of variance (ANOVA) followed by Dunnett's multiple comparison tests or two-way ANOVA with Bonferroni posttests (V4.00; GraphPad Prism Software Inc., San Diego, CA). Statistical significance was considered for $P<0.05$.

\section{Results}

Hon and Mag suppressed NMDA-induced superoxide production in neurons

Since our earlier study had demonstrated the involvement of NADPH oxidase in the production of superoxide on stimulating neurons with the ionotropic glutamate receptor agonist, NMDA [16], this protocol was used to examine the ability of Hon and Mag to suppress neuronal 
oxidative events induced by NMDA. The MTT assay was used to mark mitochondrial dysfunction and the AlamarBlue $^{\mathrm{TM}}$ assay was used to assess neuron cell death. As shown in Figure 2A, treatment of neurons with Hon and Mag (1 to $10 \mu \mathrm{M}$ ) for $24 \mathrm{~h}$ neither alters mitochondrial function nor causes neuron cell death.

Subsequently, we tested the effects of Hon and Mag on superoxide production in neurons stimulated with NMDA (100 $\mu \mathrm{M}$ for $30 \mathrm{~min})$. Treatment of neurons with NMDA elicited a large increase in superoxide production (Figure 2B, C). Hon and Mag $(10 \mu \mathrm{M})$ alone did not elicit superoxide production in neurons; however, both compounds significantly inhibited NMDA-induced superoxide production (Figure 2B, C).

\section{Hon and Mag inhibited IFNY- and LPS-induced iNOS} expression and NO production in BV-2 microglial cells As with our previous study [25], treatment of BV-2 microglial cells with IFN $\gamma+$ LPS caused the induction of iNOS expression and a correlative increase in NO production (Figure 3). Hon and, to a lesser extent, Mag inhibited LPS+IFN $\gamma$-induced iNOS expression and $\mathrm{NO}$ production in BV-2 cells in a dose-dependent manner (Figure 3). Significant inhibition of NO $(P<0.05)$ by Hon was observed at $1 \mu \mathrm{M}$, whereas significant inhibition for Mag was observed at $6 \mu \mathrm{M}$. Western blot analysis also indicated a dose-dependent inhibition of iNOS protein expression by Hon and Mag (Figure 3B, C).

Similar to results observed by our earlier study [25], addition of IFN $\gamma$ to BV-2 microglial cells greatly stimulated LPS-induced iNOS expression and NO production. Under this condition, Hon and, to a lesser extent, Mag could dose-dependently inhibit the induction of iNOS and $\mathrm{NO}$ induced by IFNY (Figure 4A-C). In fact, inhibition of IFN $\gamma$-induced $\mathrm{NO}$ production was similar to that using LPS + IFN $\gamma$ (Figure 3A).

To confirm the effects of Hon and Mag on IFN $\gamma$-induced NO production in other types of microglial cells, rat HAPI microglial cells were tested. As shown in Figure 5A, similar results were obtained for Hon to inhibit IFN $\gamma$-induced $\mathrm{NO}$ in HAPI cells. On the other hand, Mag appeared to provide greater inhibition in HAPI cells as compared to BV-2 cells (Figure 5B).

\section{ROS production in BV-2 microglial cells}

Although previous studies have demonstrated the ability for LPS + IFN $\gamma$ to induce ROS production in microglial cells, little is known about the source and the mechanism of action of the cytokines. In this study, a time course experiment was carried out to examine ROS production on treating BV-2 microglial cells to LPS or IFN $\gamma$. Data in Figure $6 \mathrm{~A}$ showed no detectable ROS during the initial $4 \mathrm{~h}$ after exposing cells to LPS or IFN $\gamma$. Lipopolysaccharide alone showed a slow increase in ROS after $4 \mathrm{~h}$ and peaked at $16 \mathrm{~h}$, whereas IFNy induced about 50\% more ROS than LPS. When cells were treated with IFN $\gamma$ together with LPS, there was a left shift for ROS production although the peak level was similar to that induced by IFN $\gamma$ alone (Figure 6A).

Based on the time course conditions, we used the $12 \mathrm{~h}$ time point to examine whether Hon and Mag may alter IFN $\gamma$-induced ROS production. Results indicated that Hon and, less effectively, Mag did inhibit IFN $\gamma$-induced ROS production in a dose-dependent manner. However, neither compound alone could exert obvious effects on the basal ROS production (Figure 6B, C).

\section{NADPH oxidase is involved in IFNy-induced ROS production}

We further investigated whether NADPH oxidase might be the target enzyme for the ROS induced by IFN $\gamma$ in microglial cells by testing with inhibitors commonly used for NADPH oxidase. Results show that DPI, a nonspecific oxidase inhibitor, and AEBSF, a serine protease inhibitor [26], could inhibit IFN $\gamma$-induced ROS in microglial cells in a dose-dependent manner (Figure 7A, B).

Using these inhibitors, we further tested whether IFN $\gamma$ induced ROS is critical for downstream signaling pathway leading to NO production. As shown in Figure 7C and D, DPI and AEBSF similarly inhibited IFN $\gamma$-induced NO production. Apocynin, a botanical compound known to inhibit translocation of cytosolic subunits p47phox and p67phox to the membrane complex [27], was shown to inhibit IFN $\gamma$-induced NO production albeit at high concentrations, starting at $40 \mu \mathrm{M}$ (Figure 7E).

Activation of NADPH oxidase is known to act through a complex mechanism involving activation of cytosolic subunits (p47phox, p67phox, p40phox, Rac) to dock with the membrane subunits (gp91phox, p22phox). In the past, several types of kinase have been shown to phosphorylate the cytosolic subunits (p47phox, p67phox, p40phox) [28]. In this study, double immunocytochemical staining was used to demonstrate that IFN $\gamma$ could induce the translocation of p47phox from the cytosol to dock with the gp91phox in the membrane (Figure 8), further supporting the involvement of the NADPH oxidase in the ROS production.

\section{IFNy-induced phosphorylation of MAPK/ERK1/2}

Although cytokines and LPS were shown to induce phosphorylation of ERK1/2, it is not clear whether this response is a reflection of IFN $\gamma$ [25]. Therefore, a time course assay was carried out to examine the ability of IFN $\gamma$ to induce $\mathrm{p}-\mathrm{ERK} 1 / 2$. IFN $\gamma$ induced a steady increase in p-ERK1/2 expression, which was noticeable around $1 \mathrm{~h}$ and reached a plateau after $4 \mathrm{~h}$ (Figure 9A-C). Hon and, to a lesser extent, Mag inhibited IFN $\gamma$-induced ERK1/2 phosphorylation in a dose-dependent manner (Figure 10A-C). Similarly, Hon also inhibited IFN $\gamma$-induced pERK1/2 in HAPI cells (Figure 11A-C). 

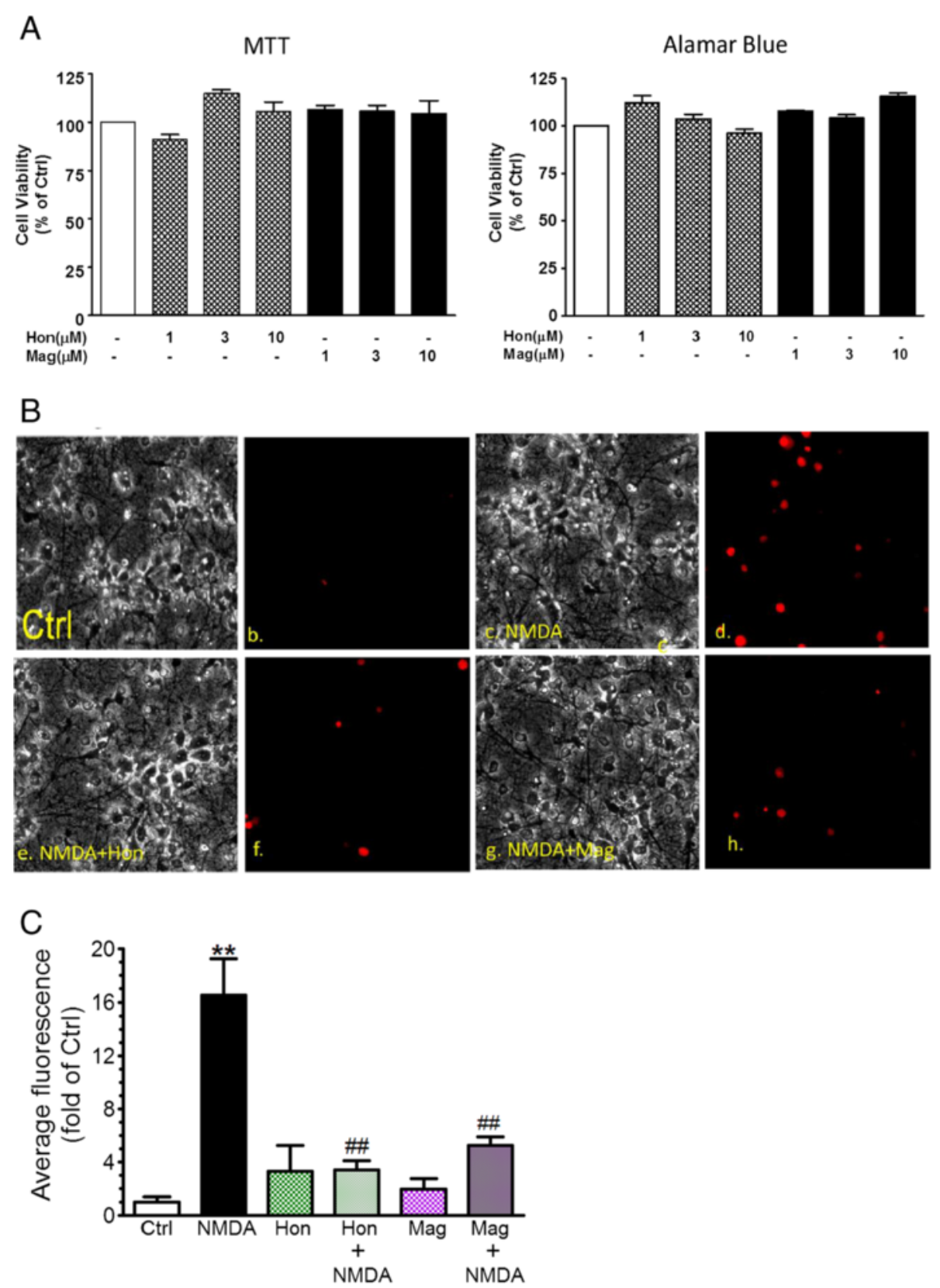

Figure 2 Hon and Mag do not alter cell viability and inhibit NMDA-induced ROS production in primary rat cortical neurons. (A) Exposure of Hon and Mag (1 to $10 \mu \mathrm{M}$ ) to primary cortical neurons for $24 \mathrm{~h}$ did not alter neuronal viability as assayed by MTT and AlamarBlue. (B) Representative bright field and DHE fluorescence photomicrographs depicting ROS production in primary neurons after cells were treated with Hon or Mag $(10 \mu \mathrm{M})$ for 30 min prior to stimulation with NMDA (100 $\mu \mathrm{M})$ for 30 min. For ROS production, neurons were loaded with dihydroethidium (DHE, $10 \mu \mathrm{M}) 30$ min prior to image acquisition under different treatment conditions. Procedure for fluorescence determination is described in text. (C) Bar graph of average fluorescence depicting significant inhibition of NMDA-induced ROS production by Hon and Mag. Data are expressed as the mean \pm SEM from three individual experiments and analyzed by two-way ANOVA with Bonferroni posttests. ${ }^{* *}$ denote significant difference between control and NMDA $(P<0.001)$, \#\# indicate significant decrease in ROS production by Hon and Mag as compared to NMDA $(P<0.01)$.

IFN $\gamma$-induced increase in p-ERK1/2 is upstream of ROS and NO production

To test whether IFN $\gamma$-induced p-ERK1/2 is upstream of ROS and NO production, the MEK1/2 inhibitor, U0126, was used to block phosphorylation of ERK1/2 by MEK1/2.
As shown in Figure 12A, U0126 effectively inhibited IFN $\gamma$ induced p-ERK1/2 in BV-2 cells. U0126 also inhibited IFN $\gamma$-induced ROS production in a dose-dependent manner, whereas U0126 did not influence basal ROS production in BV-2 cells (Figure 12B). Under similar conditions, 

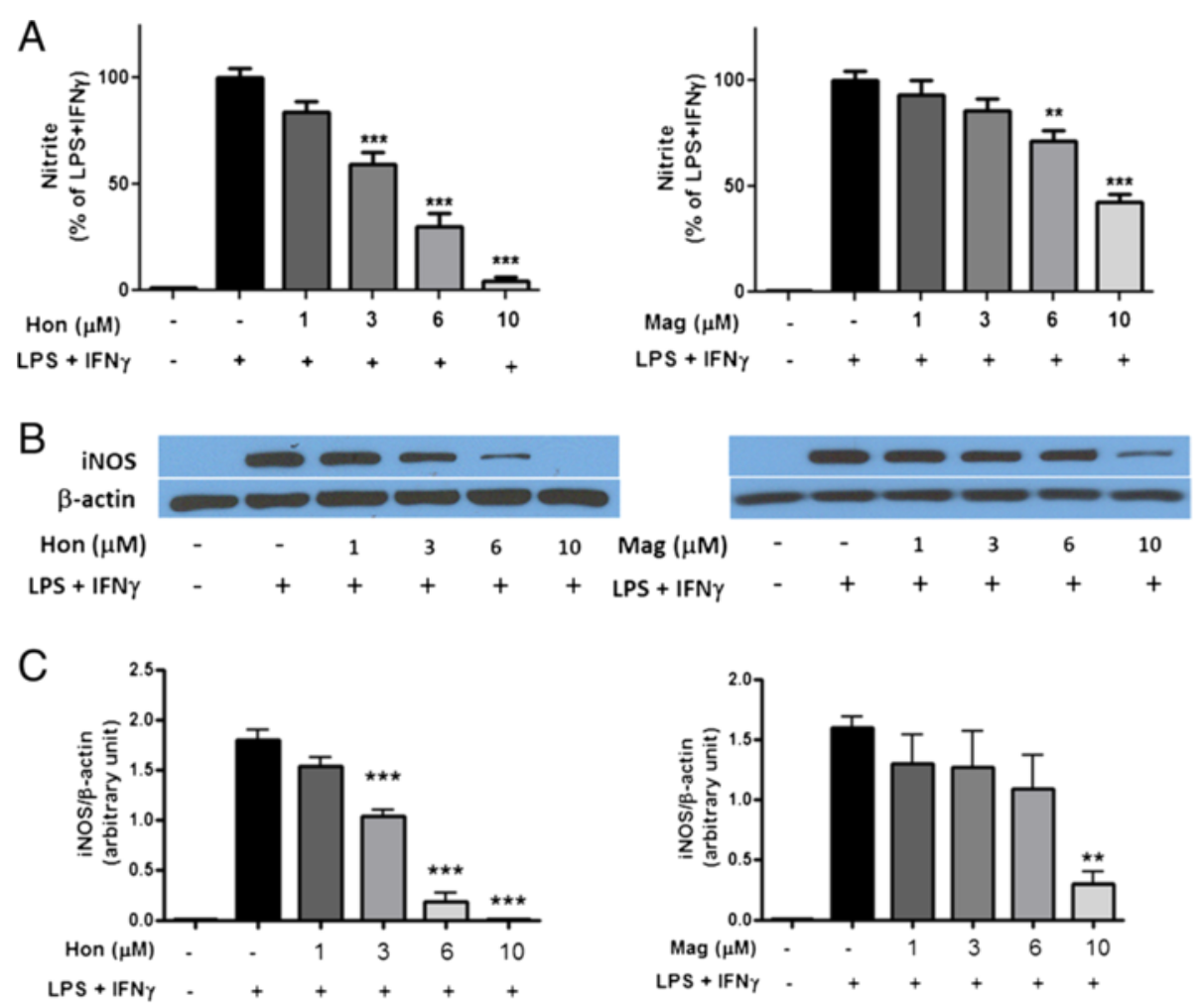

Figure 3 Hon and Mag inhibit LPS + IFNy-induced NO production and iNOS expression in BV-2 microglial cells. Cells were treated with Hon or Mag (1 to $10 \mu \mathrm{M})$ for $1 \mathrm{~h}$ followed by stimulation with LPS (100 ng/ml) + IFNy (10 ng/ml) for $16 \mathrm{~h}$. (A) Culture media were collected for determination of NO using the Griess reaction protocol as described in text. (B) Representative Western blots of iNOS protein and $\beta$-actin. (C) Bar graphs representing iNOS/ $\beta$-actin ratios. Results were expressed as the mean $\pm \operatorname{SEM}(n=3)$ and significant difference from the respective LPS + IFNY stimulated group was determined by one-way ANOVA followed by Dunnett's tests, ${ }^{* *} P<0.01 ;{ }^{* * *} P<0.001$.

U0126 was shown to inhibit IFN $\gamma$-induced NO production in BV-2 and HAPI cells (Figure 12C).

\section{Discussion}

In this study, we used rat primary cortical neurons and immortalized microglial cells (murine BV-2 and rat HAPI) to demonstrate the ability of Hon and Mag to suppress oxidative and inflammatory responses induced by NMDA in neurons and IFN $\gamma \pm$ LPS in microglial cells. Exposure of neurons to Hon and Mag (up to $10 \mu \mathrm{M}$ ) for $24 \mathrm{~h}$ did not alter neuronal viability, but both compounds $(10 \mu \mathrm{M})$ dramatically inhibited NMDA-induced superoxide production. Results from earlier studies have demonstrated involvement of NADPH oxidase in neuronal excitation $[16,17]$, and Mag and Hon were shown to offer protection against neuronal toxicity induced by hydrogen peroxide and ionotropic glutamate receptor agonist [29]. These and other results are in line with the suggestion of possible therapeutic application of these compounds to treat neurological disorders [1].

The induction of iNOS expression and NO production by pro-inflammatory cytokines and LPS is known to involve the transcriptional pathways associated with NF-kB and the canonical JAK/STAT pathway induced by IFN $\gamma$ $[22,30]$. Interestingly, in BV-2 and HAPI microglial cells, LPS and IFNY can individually stimulate iNOS/NO production, suggesting presence of cross-talk mechanisms between these two pathways [25,31,32]. There is evidence that signaling molecules, such as protein kinase $\mathrm{C}$ and mitogen-activated protein kinase (MAPK), can mediate the cross-talk pathways [22,33]. In studies with microglial cells, increase in MAPK-ERK1/2 activity has been shown to occur during induction of iNOS by LPS and IFN $\gamma$ [34-36]. Our results here also demonstrated the ability for IFN $\gamma$ alone to stimulate phosphorylation of ERK1/2 in microglial cells (Figure 9A, B). However, unlike studies in which neurons show a rapid induction of p-ERK1/2 in minutes in response to NMDA stimulation [16], phosphorylation of ERK1/2 by IFN $\gamma$ in BV-2 microglial cells turned out to be a much slower and gradual process, first observable after $1 \mathrm{~h}$ and reaching a plateau around $4 \mathrm{~h}$. In human macrophages, stimulation of p-ERK1/2 by IFN $\gamma$ exhibited an even longer delay time, of $6 \mathrm{~h}$ [37]. Apparently, the time required for ERK1/2 phosphorylation varies depending on the cell types and agonists used for activation [38]. 
A
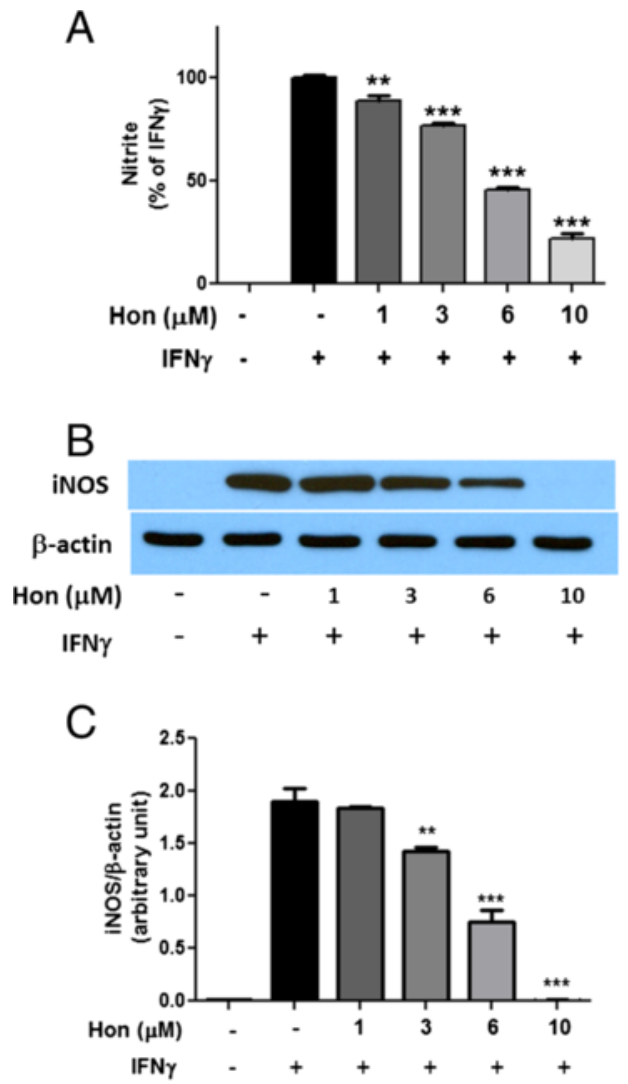
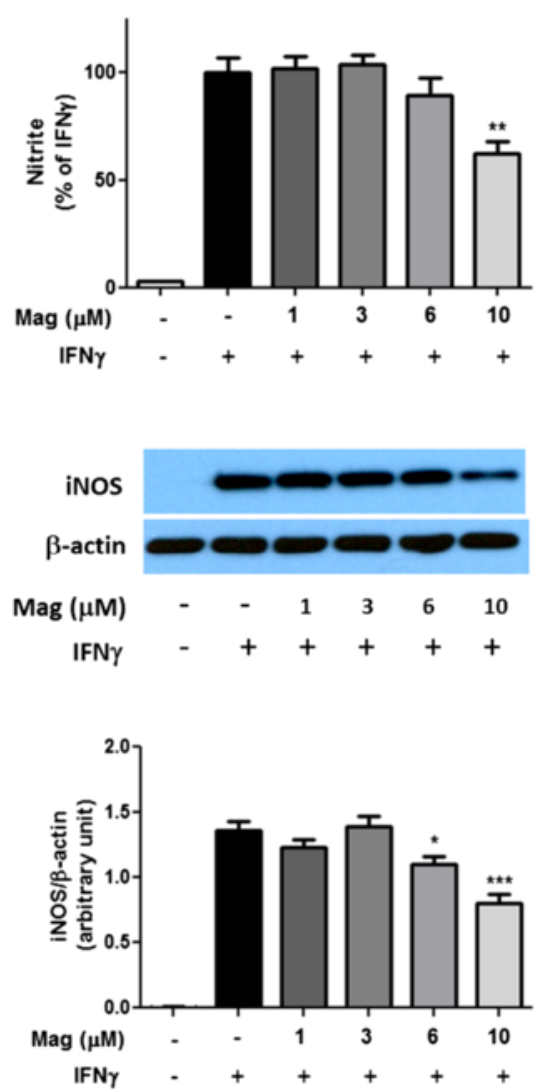

Figure 4 Hon and Mag inhibit IFNY-induced NO production and iNOS expression in BV-2 microglial cells. Cells were treated with Hon or Mag (1 to $10 \mu \mathrm{M}$ ) for $1 \mathrm{~h}$ followed by stimulation with IFNy (10 $\mathrm{ng} / \mathrm{ml}$ ) for $16 \mathrm{~h}$. (A) Culture media were collected for determination of NO using the Griess reaction protocol as described in text. (B) Representative Western blots of iNOS protein and $\beta$-actin. (C) Bar graphs representing iNOS/ $\beta$-actin ratios. Results were expressed as the mean \pm SEM $(n=3)$ and significant difference from the respective IFNY stimulated group was determined by one-way ANOVA followed by Dunnett's tests, ${ }^{*} P<0.05$, ${ }^{*} P<0.01,{ }^{* * *} P<0.001$.

Although pro-inflammatory cytokines have been shown to stimulate ROS production in microglial cells, the mechanisms for ROS production have not been clearly elucidated [39]. In our study with microglial cells, ROS production induced by LPS and IFN $\gamma$ was not observed before $4 \mathrm{~h}$ (Figure 6A). Since IFN $\gamma$-induced ROS production was inhibited by the MEK inhibitor (U0126, Figure 12B), it is reasonable to conclude that p-ERK $1 / 2$ plays an important role in the induction process. Our results support earlier studies demonstrating the involvement of ERK1/2 from IFN $\gamma$ to stimulate superoxide in a mixed glial cell culture [36]. Our study further provided evidence for involvement of NADPH oxidase in IFN $\gamma$ induced ROS production in microglial cells. Inhibitors, such as DPI and AEBSF, not only inhibited ROS but also NO production, suggesting that ROS production precedes induction of iNOS. To demonstrate further the involvement of $\mathrm{NADPH}$ oxidase in IFN $\gamma$-induced ROS production, double immunocytochemical staining showed translocation of p47phox from cytoplasm to membrane and co-localized with the gp91phox after treating cells with IFNY (Figure 8). In a study with macrophages, IFNY was shown to activate NADPH oxidase through increase in intracellular trafficking and expression of gp91phox [40].

Many extracellular signals are coupled with cell surface receptors linking to activation of the MAPK pathway. In this study, we demonstrated the role of IFNY in stimulating ROS from NADPH oxidase through the MEK-ERK1/2 pathway. Indeed, activation of ERK1/2 has been shown to elicit multiple downstream events, including phosphorylation of cytosolic phospholipase A2 (cPLA2) and arachidonic acid release in neurons [16], production of filopodia in BV-2 microglial cells [25], transcytosis of macromolecules across the epithelial monolayers [37], and enhanced phosphorylation of STAT1 [41].

Taken together, these results demonstrated a novel role of IFN $\gamma$ in stimulating the MAPK-ERK1/2 pathway, and in turn, in activating ROS production through NADPH oxidase. Since IFNy-induced p-ERK is upstream of ROS and iNOS/NO production, agents that inhibit p-ERK1/2 

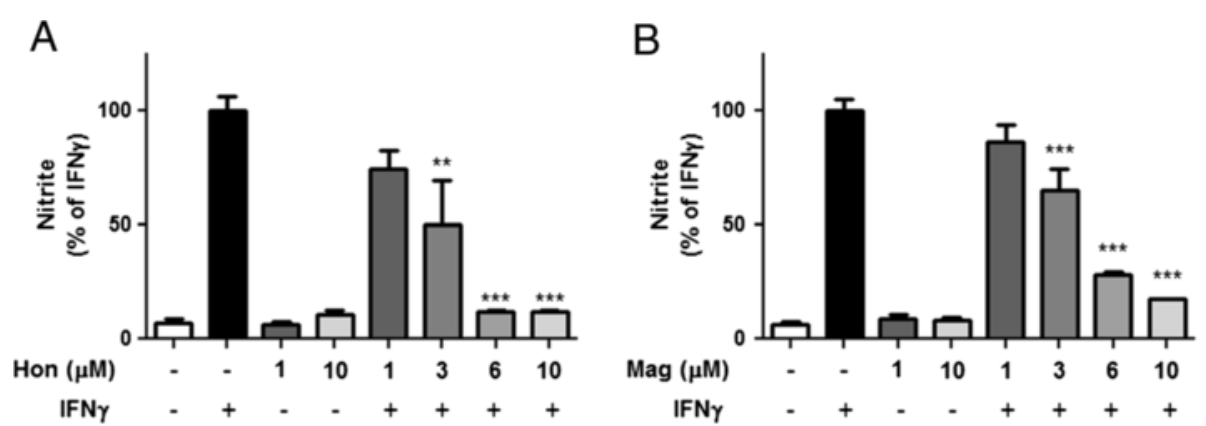

Figure $\mathbf{5}$ Hon and Mag inhibit IFNy-induced NO production in HAPI microglial cells. Cells were treated with (A) Hon or (B) Mag (1 to $10 \mu \mathrm{M})$ for $1 \mathrm{~h}$ followed by stimulation with IFNy $(10 \mathrm{ng} / \mathrm{ml})$ for $16 \mathrm{~h}$. Culture media were collected for determination of NO using the Griess reaction protocol as described in text. Results were expressed as the mean $\pm \operatorname{SEM}(n=3)$ and significant difference from the respective IFNY-stimulated group was determined by one-way ANOVA followed by Dunnett's tests, ${ }^{*} P<0.05,{ }^{* *} P<0.01,{ }^{* * *} P<0.001$.

can shut down both ROS production and iNOS induction. Understanding this mechanism helps to explain earlier observations that LPS + IFN $\gamma$ induced ROS production in microglial cells preceded the induction of iNOS [42].

Many natural polyphenols, including luteolin, gastrodin, and ginsenoside, exhibit anti-inflammatory properties and inhibit LPS/IFN $\gamma$-induced NO production in microglial cells, either through ERK1/2 or other types of MAPK [7,43-47]. Other studies have demonstrated the ability of Hon and Mag to inhibit cytokine-induced NO production and expression of iNOS, as well as generation of prostaglandins and leukotrienes [18-20,48]. Our studies unveiled the role of the IFN $\gamma$-ERK1/2 pathway in ROS production through NADPH oxidase, and the ability of Hon and Mag to suppress this oxidative and inflammatory responses in microglial cells. Understanding this mechanism can help to explain the ability of these botanicals to suppress hyperactivity in brain and retard microglial cell activation and ameliorate neuroinflammatory responses associated with neurodegenerative diseases.

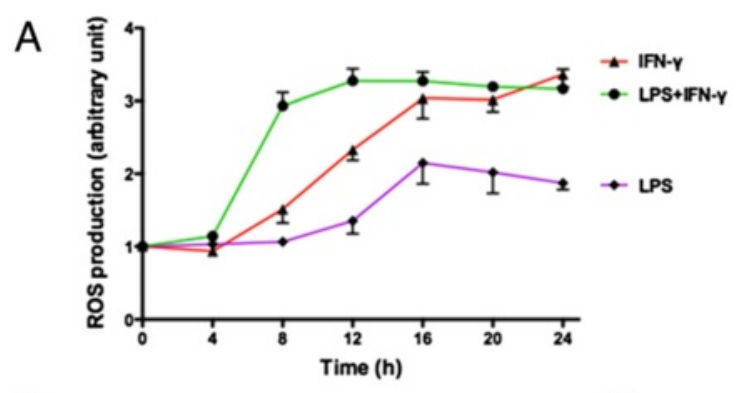

B

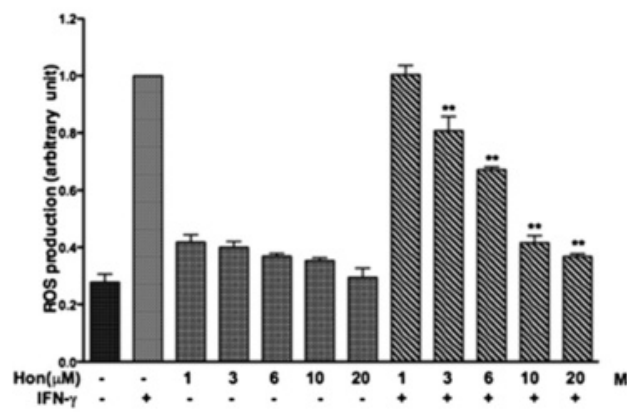

$\mathrm{C}$

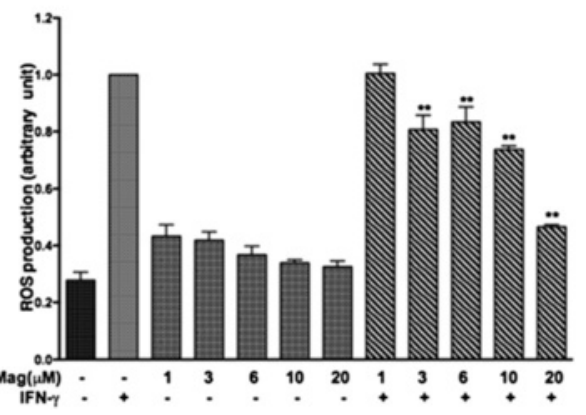

Figure 6 Hon and Mag inhibit cytokine-induced ROS production in BV-2 microglial cells. (A) Time course for ROS production induced by LPS or IFNY. Cells were treated with LPS (100 ng/ml) or IFNY (10 ng/ml) for the time indicated. ROS production was measured using CM-H2DCFDA as described in the text. Similarly, (B) Hon and (C) Mag (1 to $10 \mu \mathrm{M}$ ) were given $1 \mathrm{~h}$ prior to exposure to IFNy (10 $\mathrm{ng} / \mathrm{ml})$ for $12 \mathrm{~h}$. Results are expressed as the mean \pm SEM $(n=3)$ and significant difference from the respective IFNY-stimulated group was determined by one-way ANOVA followed by Dunnett's tests, ${ }^{*} P<0.05 ;{ }^{* *} P<0.01$. 

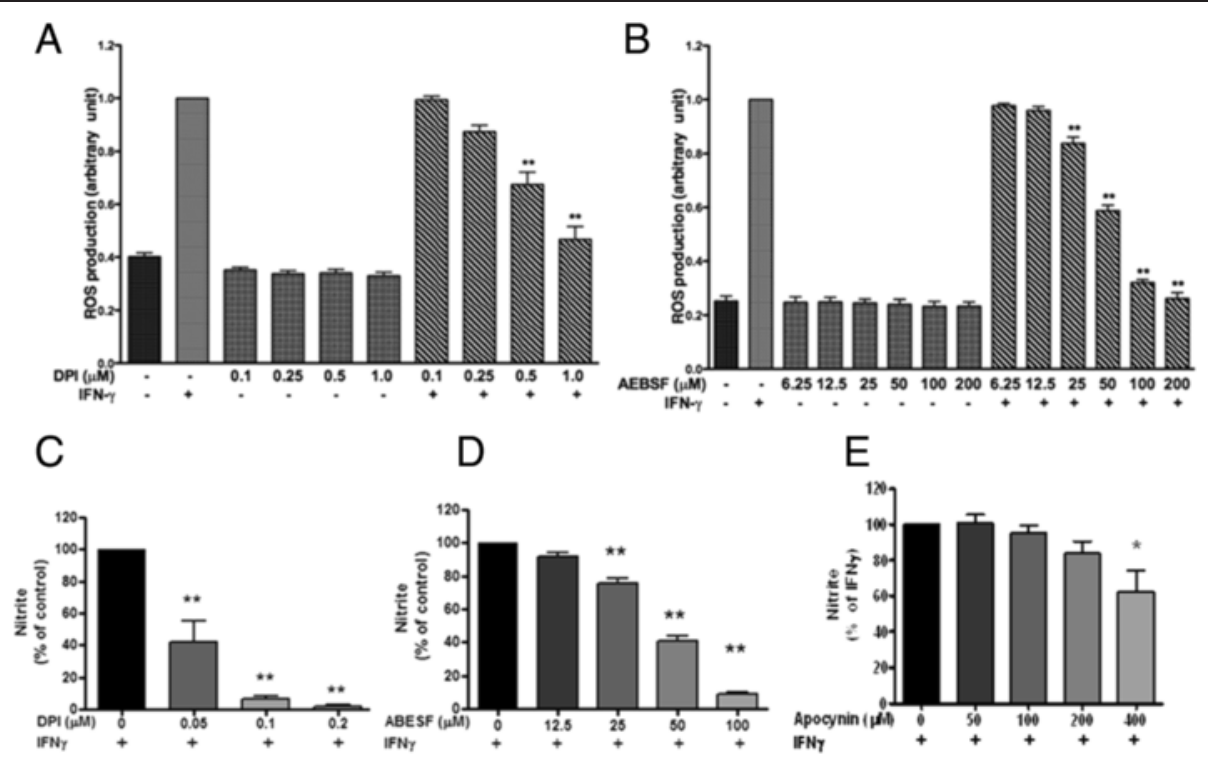

Figure 7 Activation of NADPH oxidase and ROS production is upstream of NO production in BV-2 microglial cells. Cells were pretreated with (A) DPI (0.1 to $1.0 \mu \mathrm{M})$ or (B) AEBSF $(6.25$ to $200 \mu \mathrm{M})$ for $1 \mathrm{~h}$ prior to exposure to IFNy (10 $\mathrm{ng} / \mathrm{ml})$ for $12 \mathrm{~h}$, followed by measurement of ROS with CM-H2DCFDA as described in text. Cells were pretreated with (C) DPI (0.05 to $0.2 \mu \mathrm{M})$, (D) AEBSF (12.5 to $100 \mu \mathrm{M})$, or (E) apocynin (50 to $400 \mu \mathrm{M})$ for $1 \mathrm{~h}$ prior to exposure to IFNy $(10 \mathrm{ng} / \mathrm{ml})$ for $16 \mathrm{~h}$, followed by measure of nitrite with Griess reaction protocol as described in the text. Results are expressed as the mean $\pm \operatorname{SEM}(n=3)$, and significant difference from the respective IFNY-stimulated group was determined by one-way ANOVA followed by Dunnett's tests, ${ }^{*} P<0.05 ;{ }^{* *} P<0.01$.

\section{Conclusion}

In summary, our studies with neurons and microglial cells provided strong evidence for anti-oxidative and anti-inflammatory effects of Hon and Mag and underscore the important role of NADPH oxidase in the superoxide/ROS production in these cells. Results with microglial cells further unveiled the important role of IFNY in stimulating signaling pathways involving activation of ERK1/2, ROS, and NO. These results also provide a useful and novel platform for testing anti-oxidative and anti-inflammatory effects of other botanicals.

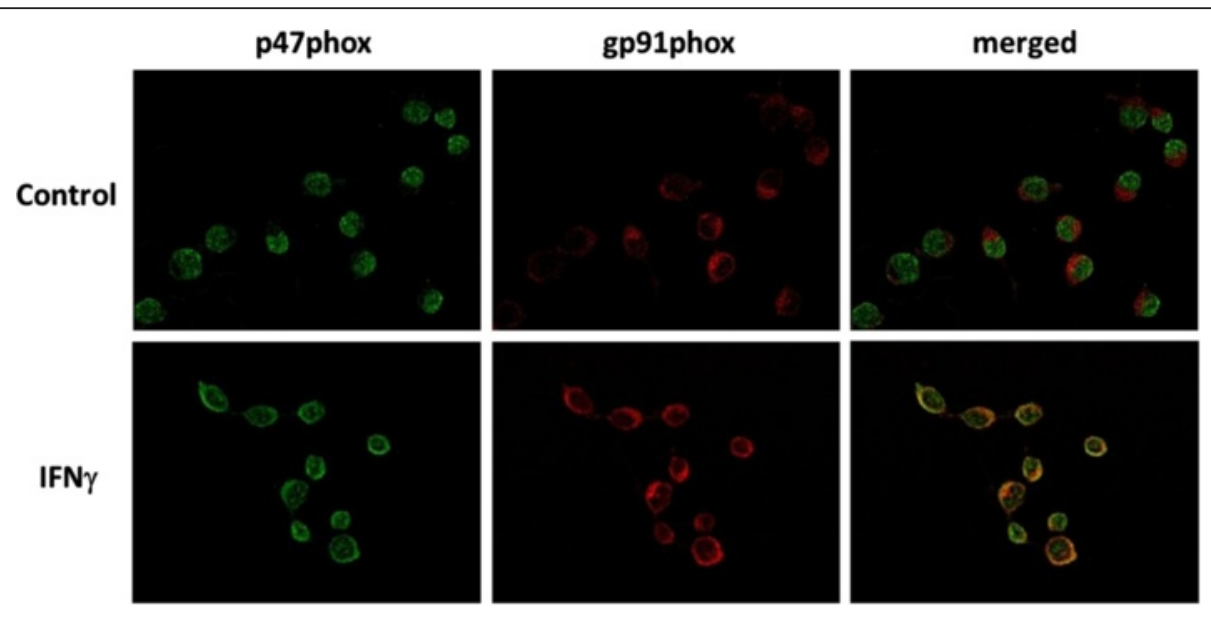

Figure 8 Involvement of NADPH oxidase in IFNy-induced NO production in BV-2 microglial cells. Cells were exposed to IFNy (10 ng/ml) for $12 \mathrm{~h}$. Immunocytochemistry was performed with antibodies against p47phox (green) and gp91phox (red). Images were taken under fluorescence microscope as serial z-stack images, followed by deconvolution processing. 

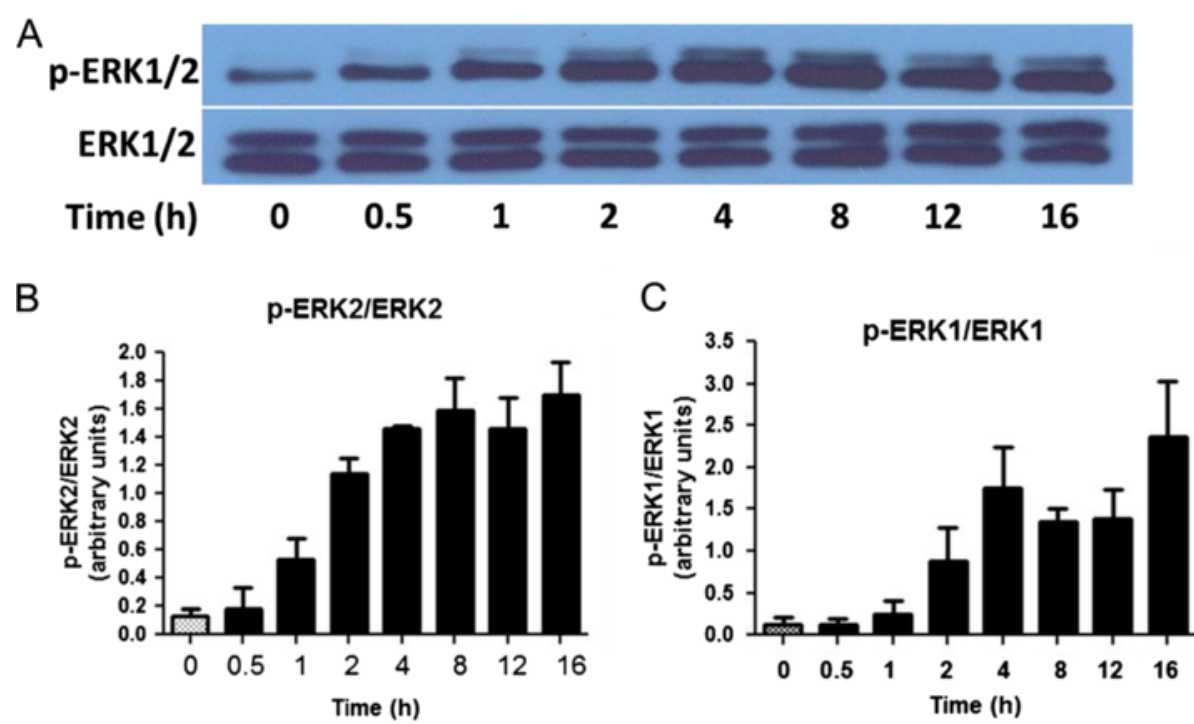

Figure 9 Time course of IFNY-induced activation of p-ERK1/2 in BV-2 microglial cells. (A) Western blot analysis of a typical time course for IFNY $(10 \mathrm{ng} / \mathrm{ml})$ to induce ERK1/2 phosphorylation in BV-2 microglia cells. Cell lysates were extracted at the time indicated. (B, C) Results of protein band intensities are expressed as arbitrary units of phospho-ERK1/2 against total ERK1/2 for (B) ERK1 and (C) ERK2. Results are expressed as mean $\pm \operatorname{SEM}(n=3)$

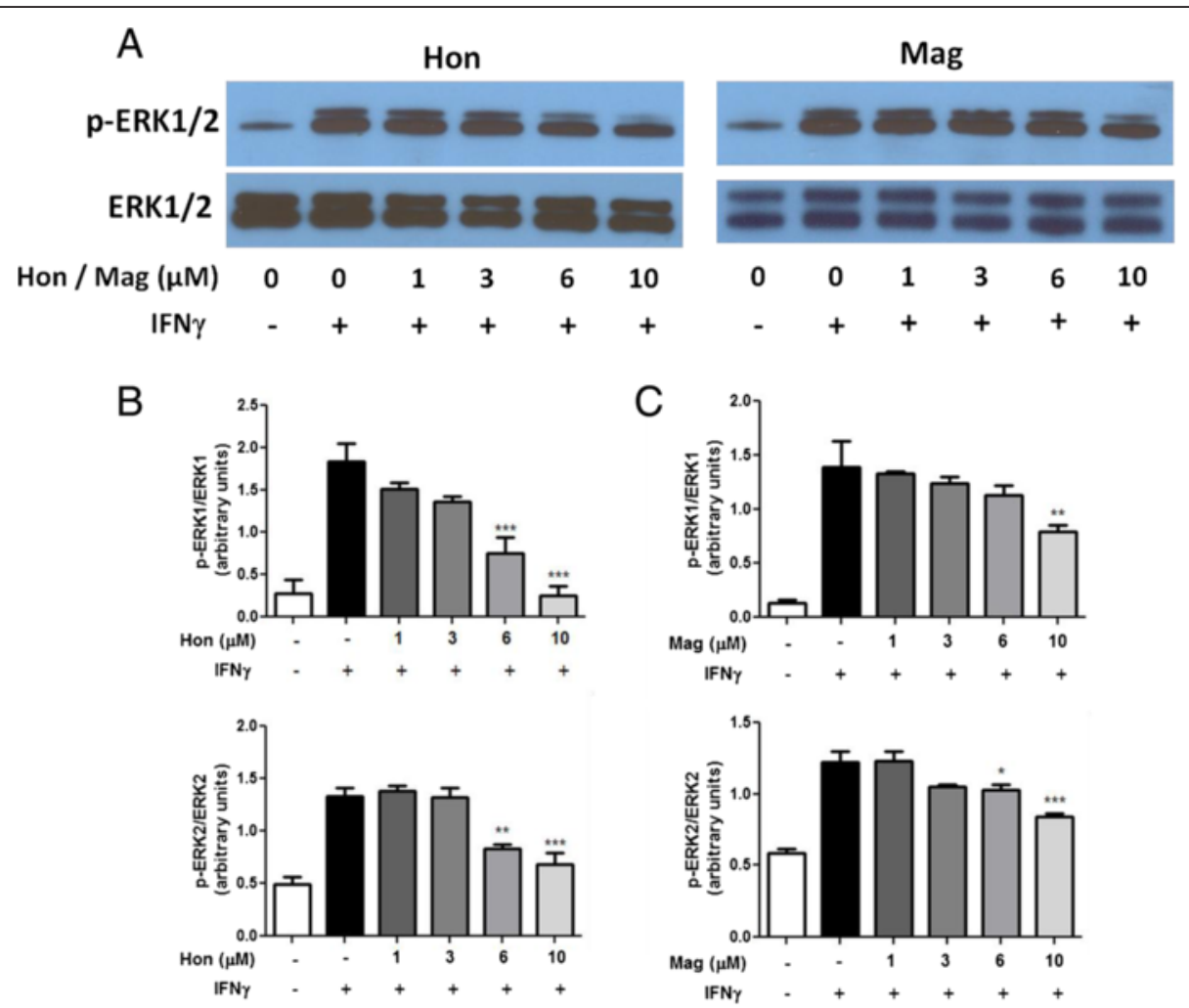

Figure 10 Hon and Mag inhibit IFNy-induced activation of p-ERK1/2 in BV-2 microglial cells. (A) Western blot analysis showing a

representative experiment of Hon or Mag pretreatment on IFNY to induce p-ERK1/2 phosphorylation in BV-2 microglia cells. Cells were treated with either Hon or Mag (1 to $10 \mu \mathrm{M})$ for $1 \mathrm{~h}$ followed by stimulation with IFNy (10 $\mathrm{ng} / \mathrm{ml})$ for $4 \mathrm{~h}$. (B \& C) Results of protein band intensities are expressed as arbitrary units of phospho-ERK1/2 against total ERK1/2. Results are expressed as the mean $\pm \operatorname{SEM}(n=3)$ and significant difference from the respective IFNy stimulated group was determined by one-way ANOVA followed by Dunnett's tests, ${ }^{*} P<0.05$; ${ }^{* *} P<0.01$; ${ }^{* * *} P<0.001$. 

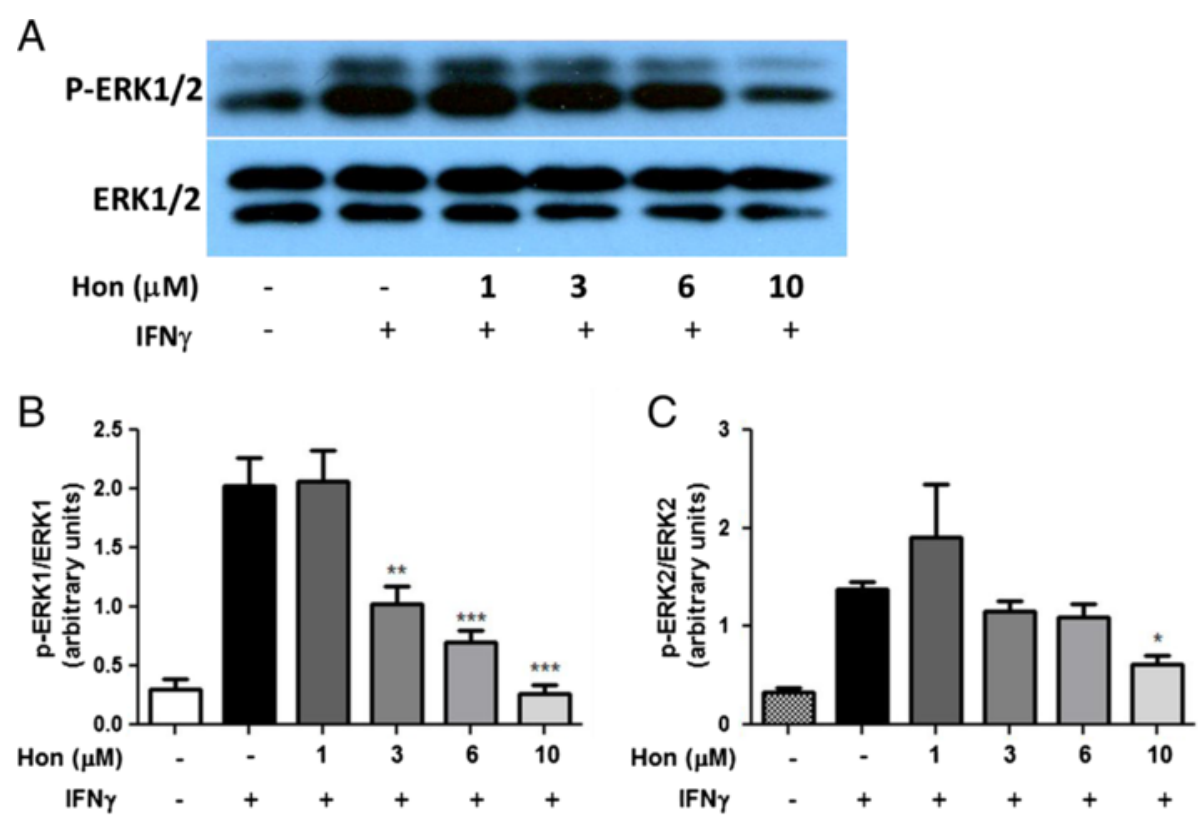

Figure 11 Hon inhibits IFN $\gamma$-induced activation of p-ERK1/2 in HAPI microglial cells. (A) Western blot analysis showing a representative experiment of Hon pretreatment on IFNy to induce ERK1/2 phosphorylation in HAPI microglial cells. Cells were treated with Hon (1 to $10 \mu \mathrm{M})$ for $1 \mathrm{~h}$ followed by stimulation with IFNY $(10 \mathrm{ng} / \mathrm{ml})$ for $4 \mathrm{~h}$. (B \& C) Results of protein band intensities are expressed as arbitrary units of phospho-ERK1/2 against total ERK1/2. Results are expressed as the mean \pm SEM $(n=3)$ and significant difference from the respective IFNy stimulated group was determined by one-way ANOVA followed by Dunnett's tests, ${ }^{*} P<0.05$; ${ }^{* *} P<0.01 ;{ }^{* * *} P<0.001$.

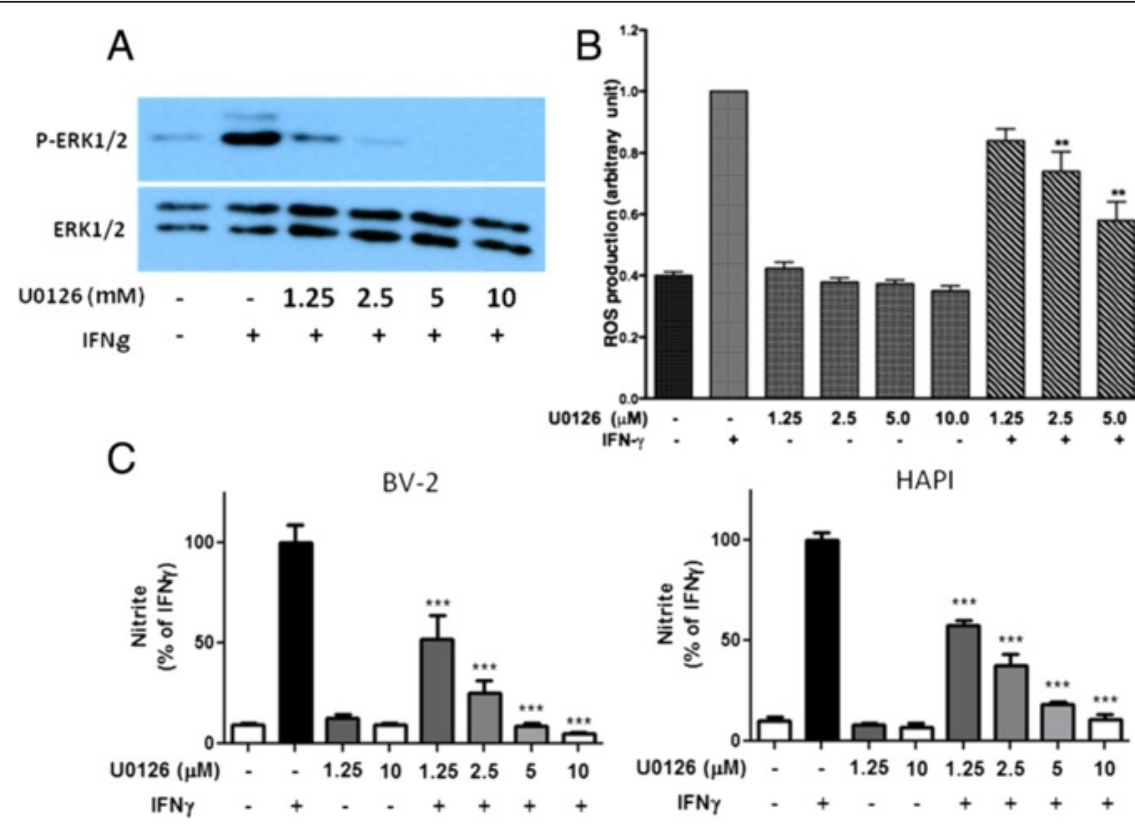

Figure 12 Role of ERK1/2 activation in IFNY-induced ROS and NO production in BV-2 and HAPI microglial cells. Cells were treated with IFNY $(10 \mathrm{ng} / \mathrm{ml})$ with or without the MEK1/2 inhibitor, U0126 (1.25 to $10 \mu \mathrm{M})$. (A) Representative Western blot demonstrated ability for U0126 to inhibit phosphorylation of ERK1/2 dose-dependently $4 \mathrm{~h}$ after IFNY treatment. (B) For ROS production, BV-2 cells were pretreated with different concentrations of U0126 for $1 \mathrm{~h}$ prior to stimulation with IFNy for $12 \mathrm{~h}$. (C) For NO production, both BV-2 and HAPI cells were pretreated with different concentrations of U0126 for $1 \mathrm{~h}$ prior to stimulation with IFNy for $16 \mathrm{~h}$. Results are expressed as the mean \pm SEM $(n=3)$, and significant difference from the respective IFNy stimulated group was determined by one-way ANOVA followed by Dunnett's tests, ${ }^{* *} P<0.01$; *** $P<0.001$. 


\section{Abbreviations}

AEBSF: 4-(2-aminoethyl)-benzenesulfonylfluoride; ANOVA: Analysis of variance; BSA: Bovine serum albumen; CCD: Charge-coupled device; DCF: CM-H2DCFDA; DHE: Dihydroethidium; DMEM: Dulbecco's modified Eagle's medium; DMSO: Dimethyl sulfoxide; DPI: Diphenyleneiodonium; FBS: Fetal bovine serum; HPLC: High performance liquid chromatography; IFNY: Interferon- $\gamma ;$ iNOS: Inducible nitric oxide synthase; LPS: Lipopolysaccharide; MAPK: Mitogen-activated protein kinase; MTT: Methylthiazolyldiphenyl-tetrazolium bromide; $\mathrm{NIH}$ : National Institutes of Health; NMDA: N-methyl-D-aspartate; NO: Nitric oxide; PBS: Phosphatebuffered saline; RIPA: Radioimmunoprecipitation assay; ROS: Reactive oxygen species; SDS: Sodium dodecyl sulfate; SEM: Standard error of the mean; TBS: Tris-buffered saline.

\section{Competing interests}

The authors do not have competing interests.

\section{Authors' contributions}

DYC carried out the studies to elucidate IFNY-ERK1/2 pathway and immunocytochemistry, MHC provided the botanicals and carried out initial studies to test Hon and Mag on cytokine-induced iNOS while visiting the University of Missouri, YZ contributed to studies on ROS in microglial cells and the elucidation of NADPH oxidase, WS carried out initial cell culture studies, YH participated in studies with neurons, JHJ carried out studies to test the effects of Hon and Mag on NADPH oxidase, JC assisted in preparation of the primary neurons, JCL contributed the protocol for assay of ROS in neurons, AS participated in the design of the study and performed the statistical analysis. While GYS is the leader of this project, DYC, MHC, AS, $\mathrm{ZG}, \mathrm{KLF}, \mathrm{WRF}, \mathrm{DBL}$, and AYS participated in discussions of concepts, and coordinated and helped in drafting the manuscript. All authors have read and approved the final manuscript.

\section{Authors' information}

This work is dedicated to Dr. Albert Y. Sun, who devoted his life to the study of polyphenols in health and diseases. He passed away on 30 April 2012.

\section{Acknowledgements}

This work is supported by NIH grants 2P01 AG08357 from NIA, 1P50 AT006273 from NCCAM, ODS and NCl, and a grant (99-2918--1-320-001) from the National Science Council, Taiwan.

\section{Author details \\ ${ }^{1}$ Interdisciplinary Neuroscience Program, University of Missouri, Columbia, MO, USA. ${ }^{2}$ Center of Translational Neuroscience, School of Medicine, University of Missouri, Columbia, MO, USA. ${ }^{3} \mathrm{MU}$ Center for Botanical Interaction Studies, Columbia, MO, USA. ${ }^{4}$ Institute of Neuroscience, National Chengchi University, Taipei, Taiwan. ${ }^{5}$ Department of Biochemistry, University of Missouri, Columbia, MO, USA. ${ }^{6}$ Department of Biology, Program in Neuroscience, Syracuse University, Syracuse, NY 13244, USA. ${ }^{7}$ Department of Pathology and Anatomical Sciences, University of Missouri, Columbia, MO, USA. ${ }^{8}$ Department of Animal Sciences, University of Missouri, Columbia, MO, USA. ${ }^{9}$ Department of Biological Engineering, University of Missouri, Columbia, MO, USA.}

Received: 11 August 2012 Accepted: 17 January 2013

Published: 29 January 2013

\section{References}

1. Lee YJ, Lee YM, Lee CK, Jung JK, Han SB, Hong JT: Therapeutic applications of compounds in the Magnolia family. Pharmacol Ther 2011, 130(2):157-176.

2. Ito K, lida T, Ichino K, Tsunezuka M, Hattori M, Namba T: Obovatol and obovatal, novel biphenyl ether lignans from the leaves of Magnolia obovata Thunb. Chem Pharm Bull(Tokyo) 1982, 30(9):3347-3353.

3. Tachikawa E, Takahashi M, Kashimoto T: Effects of extract and ingredients isolated from Magnolia obovata thunberg on catecholamine secretion from bovine adrenal chromaffin cells. Biochem Pharmacol 2000, 60(3):433-440.

4. Zhou HY, Shin EM, Guo LY, Youn UJ, Bae K, Kang SS, Zou LB, Kim YS: Antiinflammatory activity of 4-methoxyhonokiol is a function of the inhibition of iNOS and COX-2 expression in RAW 264.7 macrophages via NF-KB, JNK and p38 MAPK inactivation. Eur J Pharmacol 2008, 586(1-3):340-349.
5. Tsai SK, Huang CH, Huang SS, Hung LM, Hong CY: Antiarrhythmic effect of magnolol and honokiol during acute phase of coronary occlusion in anesthetized rats: influence of L-NAME and aspirin. Pharmacology 1999, 59(5):227-233.

6. Lu YC, Chen HH, Ko CH, Lin YR, Chan MH: The mechanism of honokiolinduced and magnolol-induced inhibition on muscle contraction and $\mathrm{Ca}^{2+}$ mobilization in rat uterus. Naunyn Schmiedebergs Arch Pharmacol 2003, 368(4):262-269.

7. Chang CP, Hsu YC, Lin MT: Magnolol protects against cerebral ischaemic injury of rat heatstroke. Clin Exp Pharmacol Physiol 2003, 30(5-6):387-392.

8. Ikarashi Y, Yuzurihara M, Sakakibara I, Nakai Y, Hattori N, Maruyama Y: Effects of the extract of the bark of Magnolia obovata and its biphenolic constituents magnolol and honokiol on histamine release from peritoneal mast cells in rats. Planta Med 2001, 67(8):709-713.

9. Liou KT, Shen YC, Chen CF, Tsao CM, Tsai SK: The anti-inflammatory effect of honokiol on neutrophils: mechanisms in the inhibition of reactive oxygen species production. Eur J Pharmacol 2003, 475(1-3):19-27.

10. Watanabe $K$, Watanabe $H$, Goto $Y$, Yamaguchi M, Yamamoto N, Hagino K: Pharmacological properties of magnolol and hōnokiol extracted from Magnolia officinalis: central depressant effects. Planta Med 1983, 49(2):103-108.

11. Maruyama Y, Kuribara H, Morita M, Yuzurihara M, Weintraub ST: Identification of magnolol and honokiol as anxiolytic agents in extracts of saiboku-to, an oriental herbal medicine. J Nat Prod 1998, 61(1):135-138.

12. Liu B, Hattori N, Zhang NY, Wu B, Yang L, Kitagawa K, Xiong ZM, Irie T, Inagaki $C$ : Anxiolytic agent, dihydrohonokiol-B, recovers amyloid $\beta$ protein-induced neurotoxicity in cultured rat hippocampal neurons. Neurosci Lett 2005, 384(1-2):44-47.

13. Chen HH, Lin SC, Chan MH: Protective and restorative effects of magnolol on neurotoxicity in mice with 6-hydroxydopamine-induced hemiparkinsonism. Neurodegener Dis 2011, 8(5):364-374.

14. Xu Q, Yi LT, Pan Y, Wang X, Li YC, Li JM, Wang CP, Kong LD: Antidepressant-like effects of the mixture of honokiol and magnolol from the barks of Magnolia officinalis in stressed rodents. Prog Neuropsychopharmacol Biol Psychiatry 2008, 32(3):715-725.

15. Chang-Mu C, Jen-Kun L, Shing-Hwa L, Shoei-Yn LS: Characterization of neurotoxic effects of NMDA and the novel neuroprotection by phytopolyphenols in mice. Behav Neurosci 2010, 124(4):541-553.

16. Shelat PB, Chalimoniuk M, Wang JH, Strosznajder JB, Lee JC, Sun AY, Simonyi A, Sun GY: Amyloid beta peptide and NMDA induce ROS from NADPH oxidase and AA release from cytosolic phospholipase $A_{2}$ in cortical neurons. J Neurochem 2008, 106(1):45-55.

17. Brennan AM, Suh SW, Won SJ, Narasimhan P, Kauppinen TM, Lee H, Edling Y, Chan PH, Swanson RA: NADPH oxidase is the primary source of superoxide induced by NMDA receptor activation. Nat Neurosci 2009, 12(7):857-863.

18. Oh JH, Kang LL, Ban JO, Kim YH, Kim KH, Han SB, Hong JT: Antiinflammatory effect of 4-0-methylhonokiol, compound isolated from Magnolia officinalis through inhibition of NF-KB [corrected]. Chem Biol Interact 2009, 180(3):506-514.

19. Kuo DH, Lai YS, Lo CY, Cheng AC, Wu H, Pan MH: Inhibitory effect of magnolol on TPA-induced skin inflammation and tumor promotion in mice. J Agric Food Chem 2010, 58(9):5777-5783.

20. Wu F, Zhang W, Li L, Zheng F, Shao X, Zhou J, Li H: Inhibitory effects of honokiol on lipopolysaccharide-induced cellular responses and signaling events in human renal mesangial cells. Eur J Pharmacol 2011, 654(1):117-121.

21. He Y, Cui J, Lee JC, Ding S, Chalimoniuk M, Simonyi A, Sun AY, Gu Z, Weisman GA, Wood WG, Sun GY: Prolonged exposure of cortical neurons to oligomeric amyloid- $\beta$ impairs NMDA receptor function via NADPH oxidase-mediated ROS production: protective effect of green tea (-)-epigallocatechin-3-gallate. ASN Neuro 2011, 3(1):e00050.

22. Shen S, Yu S, Binek J, Chalimoniuk M, Zhang X, Lo SC, Hannink M, Wu J, Fritsche K, Donato R, Sun GY: Distinct signaling pathways for induction of type II NOS by IFNY and LPS in BV-2 microglial cells. Neurochem Int 2005, 47(4):298-307.

23. Chapman KE, Sinclair SE, Zhuang D, Hassid A, Desai LP, Waters CM: Cyclic mechanical strain increases reactive oxygen species production in pulmonary epithelial cells. Am J Physiol Lung Cell Mol Physiol 2005, 289:L834-L841.

24. Forkink M, Smeitink JA, Brock R, Willems PH, Koopman WJ: Detection and manipulation of mitochondrial reactive oxygen species in mammalian cells. Biochim Biophys Acta 2010, 1797(6-7):1034-1044.

25. Sheng W, Zong Y, Mohammad A, Ajit D, Cui J, Han D, Hamilton JL, Simonyi A, Sun AY, Gu Z, Hong JS, Weisman GA, Sun GY: Pro-inflammatory cytokines 
and lipopolysaccharide induce changes in cell morphology, and upregulation of ERK1/2, iNOS and SPLA(2)-IIA expression in astrocytes and microglia. J Neuroinflammation 2011, 8:121.

26. Diatchuk V, Lotan O, Koshkin V, Wikstroem P, Pick E: Inhibition of NADPH oxidase activation by 4-(2-aminoethyl)-benzenesulfonyl fluoride and related compounds. J Biol Chem 1997, 272:13292-301.

27. Stolk J, Hiltermann TJ, Dijkman JH, Verhoeven AJ: Characteristics of the inhibition of NADPH oxidase activation in neutrophils by apocynin, a methoxy-substituted catechol. Am J Respir Cell Mol Biol 1994, 11(1):95-102.

28. Bokoch GM, Diebold B, Kim JS, Gianni D: Emerging evidence for the importance of phosphorylation in the regulation of NADPH oxidases. Antioxid Redox Signal 2009, 11(10):2429-2441.

29. Lin YR, Chen HH, Ko CH, Chan MH: Neuroprotective activity of honokiol and magnolol in cerebellar granule cell damage. Eur J Pharmacol 2006, 537(1-3):64-69.

30. Marcus JS, Karackattu SL, Fleegal MA, Sumners C: Cytokine-stimulated inducible nitric oxide synthase expression in astroglia: role of Erk mitogen-activated protein kinase and NF-KB. Glia 2003, 41(2):152-160.

31. Otero M, Lago R, Gómez R, Lago F, Gomez-Reino JJ, Gualillo O: Phosphatidylinositol 3-kinase, MEK-1 and p38 mediate leptin/interferongamma synergistic NOS type II induction in chondrocytes. Life Sci 2007, 81(19-20):1452-1460.

32. Mir M, Asensio VJ, Tolosa L, Gou-Fabregas M, Soler RM, Lladó J, Olmos G: Tumor necrosis factor alpha and interferon gamma cooperatively induce oxidative stress and motoneuron death in rat spinal cord embryonic explants. Neuroscience 2009, 162(4):959-971.

33. Chao LK, Liao PC, Ho CL, Wang El, Chuang CC, Chiu HW, Hung LB, Hua KF: Antiinflammatory bioactivities of honokiol through inhibition of protein kinase $C$, mitogen-activated protein kinase, and the NF-KB pathway to reduce LPSinduced TNFa and NO expression. J Agric Food Chem 2010, 58(6):3472-3478

34. Chan ED, Riches DW: IFN- $\gamma$ + LPS induction of iNOS is modulated by ERK, JNK/SAPK, and p38 ${ }^{\text {mapk }}$ in a mouse macrophage cell line. Am J Physiol Cell Physiol 2001, 280(3):C441-C450.

35. Blanchette J, Jaramillo M, Olivier M: Signalling events involved in interferon- $\gamma$-inducible macrophage nitric oxide generation. Immunology 2003, 108(4):513-522.

36. Herrera-Molina R, Flores B, Orellana JA, von Bernhardi R: Modulation of interferon- $\gamma$-induced glial cell activation by transforming growth factor $\beta 1$ : a role for STAT1 and MAPK pathways. J Neurochem 2012, 123(1):113-123.

37. Smyth D, Phan V, Wang A, McKay DM: Interferon- $\gamma$-induced increases in intestinal epithelial macromolecular permeability requires the Src kinase Fyn. Lab Invest 2011, 91(5):764-777.

38. Saud K, Herrera-Molina R, Von Bernhardi R: Pro- and anti-inflammatory cytokines regulate the ERK pathway: implication of the timing for the activation of microglial cells. Neurotox Res 2005, 8(3-4):277-287.

39. Zhao S, Zhang L, Lian G, Wang X, Zhang H, Yao X, Yang J, Wu C: Sildenafil attenuates LPS-induced pro-inflammatory responses through downregulation of intracellular ROS-related MAPK/NF-KB signaling pathways in N9 microglia. Int Immunopharmacol 2011, 11(4):468-474.

40. Casbon AJ, Long ME, Dunn KW, Allen LA, Dinauer MC: Effects of IFN- $\gamma$ on intracellular trafficking and activity of macrophage NADPH oxidase flavocytochrome b558. J Leukoc Biol 2012, 92(4):869-882.

41. Li N, McLaren JE, Michael DR, Clement M, Fielding CA, Ramji DP: ERK is integral to the IFN- $\gamma$-mediated activation of STAT1, the expression of key genes implicated in atherosclerosis, and the uptake of modified lipoproteins by human macrophages. J Immunol 2010, 185(5):3041-3048.

42. Pawate $S$, Shen $Q$, Fan F, Bhat NR: Redox regulation of glial inflammatory response to lipopolysaccharide and interferony. J Neurosci Res 2004, 77(4):540-551

43. Kao TK, Ou YC, Lin SY, Pan HC, Song PJ, Raung SL, Lai CY, Liao SL, Lu HC, Chen CJ: Luteolin inhibits cytokine expression in endotoxin/cytokinestimulated microglia. J Nutr Biochem 2011, 22(7):612-624.

44. Dai JN, Zong Y, Zhong LM, Li YM, Zhang W, Bian LG, Ai QL, Liu YD, Sun J, Lu D: Gastrodin inhibits expression of inducible NO synthase, cyclooxygenase-2 and proinflammatory cytokines in cultured LPSstimulated microglia via MAPK pathways. PLoS One 2011, 6(7):e21891.

45. Jung HW, Seo UK, Kim JH, Leem KH, Park YK: Flower extract of Panax notoginseng attenuates lipopolysaccharide-induced inflammatory response via blocking of NF-KB signaling pathway in murine macrophages. J Ethnopharmacol 2009, 122(2):313-319.
46. Liou KT, Shen YC, Chen CF, Tsao CM, Tsai SK: Honokiol protects rat brain from focal cerebral ischemia-reperfusion injury by inhibiting neutrophil infiltration and reactive oxygen species production. Brain Res 2003, 992(2):159-166.

47. Jung JS, Kim DH, Kim HS: Ginsenoside Rh1 suppresses inducible nitric oxide synthase gene expression in IFN- $\gamma$-stimulated microglia via modulation of JAK/STAT and ERK signaling pathways. Biochem Biophys Res Commun 2010, 397(2):323-328.

48. Kang JS, Lee KH, Han MH, Lee H, Ahn JM, Han SB, Han G, Lee K, Park SK, Kim HM: Antiinflammatory activity of methanol extract isolated from stem bark of Magnolia kobus. Phytother Res 2008, 22(7):883-888.

doi:10.1186/1742-2094-10-15

Cite this article as: Chuang et al.: Magnolia polyphenols attenuate oxidative and inflammatory responses in neurons and microglial cells. Journal of Neuroinflammation 2013 10:15.

\section{Submit your next manuscript to BioMed Central and take full advantage of:}

- Convenient online submission

- Thorough peer review

- No space constraints or color figure charges

- Immediate publication on acceptance

- Inclusion in PubMed, CAS, Scopus and Google Scholar

- Research which is freely available for redistribution 